\title{
Psoriasis in areas difficult to treat and biological therapy
}

\section{Łuszczyca w trudnych do leczenia lokalizacjach a terapia biologiczna}

\author{
Anna Lis-Święty, Aleksandra Frątczak \\ Department of Dermatology, Faculty of Medical Sciences, Medical University of Silesia, Katowice, Poland \\ Katedra i Klinika Dermatologii, Wydział Nauk Medycznych, Śląski Uniwersytet Medyczny w Katowicach, Polska \\ Dermatol Rev/Przegl Dermatol 2021, 108, |7|-177 \\ DOI: https://doi.org//0.5 I 4/dr.2021.1086/5
}

\section{CORRESPONDING AUTHOR/ ADRES DO KORESPONDENCJI: dr hab. n. med. Anna Lis-Święty, prof. SUM \\ Katedra i Klinika Dermatologii Wydział Nauk Medycznych Śląski Uniwersytet Medyczny Katowice, Polska e-mail: alis-swiety@sum.edu.pl}

\begin{abstract}
Psoriasis often affects specific locations such as the nail apparatus, scalp, hands, feet, and genital areas. It usually coexists with severe plaque psoriasis. However in some cases only these areas may be affected, causing a significant deterioration of the patient's quality of life, low self-esteem and depression. In the absence of effects of a topical treatment (glucocorticosteroids in monotherapy or combined with calcipotriol, keratolytic agents, phototherapy, calcineurin inhibitors) and standard systemic therapy (i.e., retinoids, methotrexate and cyclosporin), biological drugs are often used, even though the PASI score does not exceed 10. Interleukin-17 inhibitors and interleukin-23 inhibitors, are the most adequate biological drugs for isolated psoriasis in these special anatomic locations
\end{abstract}

\section{STRESZCZENIE}

Łuszczyca często obejmuje szczególne lokalizacje, takie jak paznokcie, owłosiona skóra głowy, dłonie i/lub stopy oraz okolice genitalne. Zwykle współwystępuje z ciężką łuszczycą plackowatą, ale w niektórych przypadkach dotyczy tylko tych okolic, co powoduje znaczne obniżenie jakości życia pacjenta, niską samoocenę i stany depresyjne. W przypadku braku efektów leczenia miejscowego (glikokortykosteroidy w monoterapii lub w skojarzeniu z kalcypotriolem, środki keratolityczne, fototerapia, inhibitory kalcyneuryny) oraz standardowej terapii ogólnej, tj. retinoidy, metotreksat i cykloporyna, często stosuje się leki biologiczne, mimo że PASI nie jest powyżej 10. Inhibitory interleukiny 17 i inhibitory interleukiny 23 mają największe zastosowanie wśród leków biologicznych do leczenia łuszczycy miejsc szczególnych.

Key words: biological drugs, psoriasis, scalp, genitals, nails.

Słowa kluczowe: leki biologiczne, łuszczyca, głowa owłosiona, narządy płciowe, paznokcie.

\section{INTRODUCTION}

Psoriasis is a chronic inflammatory disease associated with autoimmune processes. The disease usually manifests as erythematous-exfoliating skin

\section{WPROWADZENIE}

Łuszczyca jest przewlekłym schorzeniem zapalnym związanym z procesami autoimmunizacyjnymi, które zwykle objawiają się w postaci rumieniowo-złuszcza- 
lesions. It often affects areas that are difficult to treat, also referred to as special areas: scalp (43-65\%), face $(30-49 \%)$, genital areas $(14-43 \%)$, hands and/or feet $(12-16 \%)$, as well as nails (23-60\%), especially in psoriatic arthritis (over $80 \%$ of patients) [1-4]. Almost $65 \%$ of people suffering from psoriasis have lesions in at least one, more than $40 \%$ in at least two, and more than $20 \%$ in at least three of the above-mentioned locations [3]. Psoriasis of special areas occurs in patients with severe course of the disease $(89 \%$ of cases) and in mild cases (even in about $80 \%$ of patients) [3]. It should be mentioned that sometimes special areas are the only location of psoriasis, e.g., only nail plates may be affected by the disease $(5-10 \%$ of cases). Occupation of visible parts of the body and genital areas (often overlooked during medical examination) leads to a feeling of stigmatization, low self-esteem, depressed mood, affects sexual functions and worsens the psychological well-being of the patient [5-9]. Quality of life questionnaires (Dermatologic Life Quality Index - DLQI, Palmoplantar Quality of Life Index) and tools such as Visual Analogue Scale for Pain (PAIN VAS), Visual Analogue Scale for Itch (ITCH VAS), Nail Area Psoriasis Severity Index (NAPSI), Psoriasis Scalp Severity Index (PSSI), Palmoplantar Psoriasis Area and Severity Index (PPPASI), Physician Global Assessment (PGA) may better reflect the severity of psoriasis when the lesion area (BSA) does not exceed $10 \%$ or the PASI severity index is over 10 points. Moreover, the functioning of a patient may be worsened by concomitant psoriatic arthritis, development of which is often associated with the occurrence of psoriatic lesions of the nails, scalp and skin folds [10]. In the case of nail psoriasis, the risk of developing psoriatic arthritis is more than double [11]. Psoriasis in special areas and nail psoriasis often pose therapeutic problems as being refractory to conventional methods of treatment (topical treatment, phototherapy, acitretin, methotrexate, cyclosporine), which results in transition to biological therapy (TNF-, interleukin-12/23-, interleukin-17and interleukin-23-inhibitors) or the implementation of small molecule drugs (apremilast, tofacitinib). This management should apply to each of the abovementioned forms of psoriasis, even if severity of the remaining psoriatic foci on the skin does not justify the diagnosis of moderate to severe psoriasis [12, 13].

The aim of the study is to present the current knowledge on the effectiveness of biological treatment, in order to help dermatologists to choose the most appropriate treatment. The analysis included articles from the PubMed database that were searched using keywords: biologics, genital psoriasis, nail psoriasis, palmoplantar psoriasis, scalp psoriasis, small molecules. jących zmian skórnych. Choroba często dotyczy okolic trudnych do leczenia, określanych też miejscami szczególnymi, takich jak skóra głowy owłosionej (43-65\%), twarzy (30-49\%), okolic genitalnych (14-43\%), dłoni i/lub stóp (12-16\%), jak również paznokci (23-60\%), zwłaszcza w łuszczycowym zapaleniu stawów (ponad $80 \%$ pacjentów) [1-4]. Prawie $65 \%$ osób chorujących na łuszczycę ma zmiany w co najmniej jednej lokalizacji, ponad $40 \%$ w co najmniej dwóch, a powyżej $20 \%$ w co najmniej trzech z wyżej wymienionych lokalizacji [3]. Łuszczyca miejsc szczególnych występuje u pacjentów z ciężkim przebiegiem choroby (w 89\% przypadków) oraz w łagodnych przypadkach (nawet u ok. $80 \%$ chorych) [3]. Należy dodać, że niekiedy szczególne miejsca są jedyną lokalizacją łuszczycy, np. procesem chorobowym mogą być objęte tylko płytki paznokciowe (5-10\% przypadków). Zajęcie widocznych części ciała i okolic genitalnych (często pomijanych w trakcie badania lekarskiego) prowadzi do poczucia stygmatyzacji, niskiej samooceny, obniżenia nastroju, wpływa na funkcje seksualne i pogarsza psychiczny dobrostan pacjenta [5-9]. Kwestionariusze jakości życia (Dermatologic Life Quality Index - DLQI, Palmoplantar Quality of Life Index) i narzędzia, takie jak Visual Analogue Scale for Pain (PAIN VAS), Visual Analogue Scale for Itch (ITCH VAS), Nail A rea Psoriasis Severity Index (NAPSI), Psoriasis Scalp Severity Index (PSSI), Palmoplantar Psoriasis Area and Severity Index (PPPASI), Physician Global Assessment (PGA), mogą lepiej odzwierciedlać nasilenie łuszczycy, gdy powierzchnia zmian chorobowych (BSA) nie przekracza $10 \%$ lub wskaźnik nasilenia PASI wynosi nie więcej niż 10 pkt. Ponadto funkcjonowanie pacjenta może pogarszać współistniejące łuszczycowe zapalenie stawów, którego rozwój bywa nierzadko powiązany z występowaniem zmian łuszczycowych paznokci, skóry owłosionej głowy oraz fałdów skórnych [10]. W przypadku łuszczycy paznokci ryzyko rozwoju łuszczycowego zapalenia stawów wzrasta nawet ponaddwukrotnie [11]. Łuszczyca w szczególnych lokalizacjach i łuszczyca paznokci często stwarza problemy terapeutyczne, nie poddając się konwencjonalnym metodom leczenia (leczenie miejscowe, fototerapia, acytretyna, metoteksat, cyklosporyna), co skutkuje przejściem do terapii biologicznej (inhibitory TNF, interleukiny 12/23, interleukiny 17 i interleukiny 23) lub wdrożeniem leków drobnocząsteczkowych (apremilast, tofacytynib). Postępowanie takie powinno dotyczyć każdej z wyżej wymienionych postaci łuszczycy, nawet gdy nasilenie pozostałych ognisk łuszczycy na skórze nie pozwala rozpoznać łuszczycy umiarkowanej do ciężkiej [12, 13].

Celem pracy jest przedstawienie aktualnej wiedzy na temat skuteczności leczenia biologicznego, tak aby ułatwić dermatologom wybór najbardziej odpowiedniego leku. W analizie uwzględniono artykuły z bazy PubMed, które wyszukano za pomocą terminów: biologics, genital psoriasis, nail psoriasis, palmoplantar psoriasis, scalp psoriasis, small molecules. 
The scalp is the most common psoriasis-affected area that is difficult to treat. Topical therapy is always preferred as the first-line treatment: glucocorticosteroids, combination of calcipotriol with betamethasone, keratolytic agents; alternatively: tar, dithranol, tazarotene, phototherapy. However, approximately two thirds of patients may require systemic treatment [14], especially when severity of scalp psoriasis is moderate to severe ( $>30 \%$ of the scalp surface area and PGA 3 on the $0-5$ scale or PASI for the scalp > 4). Psoriasis of hands and/or feet, which occurs less frequently, causes no less a therapeutic problem. For psoriasis on the face or in genital area, local treatment is even more difficult. Due to side effects, corticosteroids can only be used for a short time, and many external drugs are poorly tolerated and irritating. Calcineurin inhibitors are an additional option in the external treatment of psoriasis in these areas. They are used off-label in these indications. In the event of failure of local and systemic therapy with classic drugs, biological therapy is the next stage.

According to systematic reviews regarding available biological drugs and small molecule drugs, the best control of symptoms of scalp psoriasis is provided by interleukin-17 (IL-17) inhibitors (ixekizumab, secukinumab, brodalumab) and interleukin-23 (IL-23) inhibitors (rizankizumab, guzelkumab) $[15,16]$. This study confirms these observations, and indicates that they can also be applied to psoriasis in other special areas. The studies UNCOVER-1, UNCOVER-2 and UNCOVER-3 provided evidence that the use of ixekizumab was associated with greater improvement and faster resolution of changes in hands or feet compared to placebo and etanercept [17]. Ixekizumab was also effective in treating patients with genital psoriasis (IXORA-Q study) [18]. On the other hand, the VOYAGE 1 and VOYAGE 2 studies showed that guselkumab was more effective in the treatment of both psoriasis on the head and in the area of hands and/or feet compared to adalimumab [19]. According to a report by Megna et al. the best results in the treatment of psoriasis of the scalp and hands and/or feet in real conditions were obtained with the use of ixekizumab, followed by secukinumab [20]. The authors also presented a series of cases of scalp, hands and/or feet psoriasis, in which rizankizumab was successfully administered after finding no effects of the therapy with IL-17, IL-12/IL-23 (ustekinumab) or guselkumab [21]. The effectiveness of rizankizumab in these locations was confirmed by the observation in a larger group of patients [22]. The researchers observed only a low effect of etanercept and certolizumab pegol in reducing PSSI and PPPASI [20]. Results of the therapy with adalimumab in psoriasis of hands and/or feet, as well as psoriasis of genital

\section{ŁUSZCZYCA MIEJSC SZCZEGÓLNYCH}

Głowa owłosiona stanowi najczęstszą trudną do leczenia lokalizację łuszczycy. Jako leczenie pierwszego wyboru zawsze preferowana jest terapia miejscowa: glikokortykosteroidy, połączenie kalcypotriolu $\mathrm{z}$ betametazonem, środki keratolityczne; lub dziegcie, cygnolina, tazaroten, fototerapia. Około 2/3 chorych może jednak wymagać leczenia ogólnego [14], szczególnie gdy nasilenie łuszczycy głowy osiąga stopień umiarkowany do ciężkiego (zajęcie > 30\% powierzchni skóry głowy oraz PGA 3 w skali 0-5 lub PASI dla skóry głowy > 4). Łuszczyca dłoni i/lub stóp, występująca rzadziej, powoduje nie mniejszy problem terapeutyczny. W przypadku łuszczycy na twarzy lub w okolicach genitalnych leczenie miejscowe jest jeszcze trudniejsze. Glikokortykosteroidy ze względu na objawy uboczne można stosować tylko krótkotrwale, a wiele leków zewnętrznych jest źle tolerowanych, działając drażniąco. Dodatkową opcją w leczeniu zewnętrznym łuszczycy tych okolic są miejscowe inhibitory kalcyneuryny, które zaleca się poza wskazaniami rejestracyjnymi (off-label). W przypadku niepowodzenia terapii miejscowej i ogólnej lekami klasycznymi kolejnym etapem jest terapia biologiczna.

Według przeglądów systematycznych dotyczących dostępnych leków biologicznych i substancji drobnocząsteczkowych najlepszą kontrolę objawów łuszczycy głowy owłosionej zapewniają inhibitory interleukiny 17 (IL-17) (iksekizumab, sekukinumab, brodalumab) i interleukiny 23 (IL-23) (rizankizumab, guzelkumab) $[15,16]$. Niniejsze opracowanie potwierdza te spostrzeżenia, które można odnieść także do łuszczycy w innych szczególnych miejscach. Badania UNCOVER-1, UNCOVER-2 i UNCOVER-3 dostarczyły dowodów, że stosowanie iksekizumabu wiązało się z większą poprawą i szybszym ustępowaniem zmian na dłoniach i stopach w porównaniu z placebo i etanerceptem [17]. Iksekizumab był również skuteczny w leczeniu pacjentów z łuszczycą w okolicach genitalnych (badanie IXORA-Q) [18]. Natomiast w badaniach VOYAGE 1 i VOYAGE 2 wykazano, że guzelkumab charakteryzował się wyższą skutecznością w terapii zarówno łuszczycy na głowie, jak i w obrębie dłoni i/lub stóp [19]. Według doniesienia Megna i wsp. najlepsze efekty w leczeniu łuszczycy głowy oraz dłoni i/lub stóp w warunkach rzeczywistych uzyskuje się po stosowaniu iksekizumabu, a następnie sekukinumabu [20]. Autorzy przedstawili również serię przypadków łuszczycy skóry owłosionej głowy oraz dłoni i/lub stóp, w których po stwierdzeniu braku efektów inhibitorów IL-17, IL-12/IL-23 (ustekinumab) lub guzelkumabu zastosowano z sukcesem rizankizumab [21]. Skuteczność rizankizumabu w tych lokalizacjach potwierdziła obserwacja w większej grupie chorych [22]. Badacze zaobserwowali jedynie niewielki efekt etanerceptu i certolizumabu pegol w redukcji PSSI i PPPASI [20]. Nie było istotnych 
areas, were insignificant, but significant improvement was related to changes in the scalp [23]. According to preliminary studies by Guarene et al. a worse response to treatment with TNF inhibitors (etanercept) could depend on the presence of HLA-A Bw4-80I KIR ligands, which increase the production of TNF and reduce the activity of NK cells due to the predominant activation of KIR (killer-cell immunoglobulinlike receptors). Identification of genetic markers of response to biological therapy could therefore contribute to improving the effectiveness and lowering the costs of psoriasis therapy [24].

In addition, recent reports provided evidence of the efficacy of apremilast in the treatment of psoriasis of special areas. After the use of this drug, a significant reduction in lesions on the scalp as well as on the hands and feet was noted, associated with a rapid reduction of itch and improvement in the quality of life $[25,26]$.

\section{NAIL PSORIASIS}

Onycholysis with subungual hyperkeratosis or dystrophy involving $\geq 50 \%$ of the nailplate area within $\geq 3$ fingernails, NAPSI $\geq 16$ (on a scale of 1-160) or a significantly reduced quality of life of the patient are usually indications for systemic treatment with classical or biological drugs [27]. In mildly severe nail lesions, topical medications (nail bed involvement) or intralesional injections of glucocorticosteroids or methotrexate (matrix involvement) are recommended [28]. Combination of calcipotriol with betamethasone dipropionate, strong glucocorticosteroids in combination with keratolytic drugs, vitamin A derivatives (tazarotene) can be used in an occlusive dressing. If external treatment is unsuccessful, general therapy should be considered.

Clinical improvement (reduction of PASI and BSA) after biological treatment in psoriasis with nail involvement may be slower than in psoriasis with no nail involvement. A drug switch is also required more frequently [29-31]. Nevertheless, biological drugs seem to be more effective than classic drugs. In a study by Demirsoy et al. none of conventional systemic therapies resulted in a significant improvement in psoriatic nails at week 16 of follow-up (compared to placebo), while the effect was evident in the group of patients taking biologics [32]. However, Tosti et al. believe that with low doses of acitretin for 6-12 months, $40-50 \%$ of patients can achieve a complete or partial relief of nail disease symptoms, similar to biological therapies [33]. According to Gumusel et al. reduction of NAPSI after the treatment with methotrexate and cyclosporin was comparable, and at week 24 it was $43 \%$ and $37 \%$, respectively [34]. zmian w wynikach terapii z użyciem adalimumabu w łuszczycy na dłoniach i/lub stopach, jak również w okolicy genitalnej, ale znacząca poprawa dotyczyła zmian skóry owłosionej głowy [23]. Według wstępnych badań Guarene i wsp. gorsza odpowiedź na leczenie inhibitorami TNF (etanercept) może zależeć od występowania ligandów HLA-A Bw4-80I KIR, które wpływają na większą produkcję TNF i zmniejszają aktywność komórek NK w wyniku przewagi aktywacji KIR (killer-cell immunoglobulin-like receptors). Do poprawy skuteczności i obniżenia kosztów terapii łuszczycy mogłaby przyczynić się identyfikacja genetycznych markerów odpowiedzi na terapię biologiczną [24].

Ostatnie doniesienia dostarczyły ponadto dowodów na skuteczność apremilastu w terapii łuszczycy miejsc szczególnych. Po zastosowaniu tego leku stwierdzono znaczącą redukcję zmian na owłosionej skórze głowy oraz na dłoniach i stopach powiązaną z szybkim zmniejszeniem świądu i poprawą jakości życia [25, 26].

\section{ŁUSZCZYCA PAZNOKCI}

Onycholiza z podpaznokciową hiperkeratozą lub dystrofia obejmująca $\geq 50 \%$ powierzchni płytki w obrębie co najmniej 3 płytek paznokciowych palców rąk, NAPSI

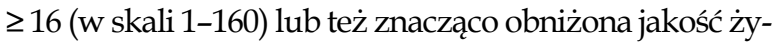
cia pacjenta są zazwyczaj wskazaniem do leczenia ogólnego lekami klasycznymi lub biologicznymi [27]. W łagodnie nasilonych zmianach paznokciowych zaleca się leki miejscowe (zajęcie łożyska) lub iniekcje doogniskowe glikokortykosteroidów lub metotreksatu (zajęcie macierzy) [28]. Połączenie kalcypotriolu z dipropionianem betametazonu, silne glikokortykosteroidy w połączeniu z lekami keratolitycznymi, pochodne witaminy A (tazaroten) można zastosować w opatrunku okluzyjnym. Jeżeli leczenie zewnętrzne nie przynosi skutku, należy rozważyć terapię ogólną.

Poprawa kliniczna (redukcja PASI i BSA) po leczeniu biologicznym w łuszczycy z zajęciem paznokci może być wolniejsza niż w łuszczycy bez zajęcia płytek paznokciowych. Częściej wymagana jest również zmiana leku [29-31]. Leki biologiczne wydają się jednak skuteczniejsze niż leki klasyczne. W badaniu Demirsoy i wsp. żadna z konwencjonalnych terapii ogólnych nie spowodowała znaczącej poprawy w zakresie zmienionych łuszczycowo paznokci w 16 . tygodniu obserwacji (w porównaniu z placebo), podczas gdy efekt był widoczny u pacjentów przyjmujących leki biologiczne [32]. Tosti i wsp. uważają jednak, że stosując acytretynę w niskich dawkach przez 6-12 miesięcy, u 40-50\% chorych można uzyskać całkowite lub częściowe ustąpienie objawów chorobowych w obrębie paznokci, podobnie jak w przypadku terapii biologicznych [33]. Według Gumusel i wsp. redukcja NAPSI po leczeniu metotreksatem i cyklosporyną była porównywalna i w 24. tygodniu wynosiła odpowiednio 43\% i 37\% [34]. 
Recently published systematic reviews and metaanalyzes confirm that all biological and small molecule drugs used in psoriasis resulted in clinical improvement in nail lesions at weeks 10-16 and in weeks 24-26 of treatment compared to placebo. The best results were observed with ixekizumab, etanercept and tofacitinib [35-37]. Complete disappearance of symptoms is most likely after treatment with ixekizumab, followed by brodalumab, adalimumab, guselkumab, ustekinumab and infliximab [38]. Results of the UNCOVER-3 study deserve attention: in patients using ixekizumab, a significant effect was seen in the week 12 of the therapy, and in over $50 \%$ of cases remission of nail psoriasis was achieved in the week 60 of the treatment [39]. The higher effectiveness of ixekizumab in reducing nail lesions compared to ustekinumab and guselkumab was confirmed in the IXORA-R and IXORA-S studies $[40,41]$. It is worth adding that in terms of skin lesions, the response to treatment with ixekizumab in patients without and with nail involvement was similar [42]. However, the TRANSFIGURE study showed a sustained improvement in nail psoriasis and patients' quality of life with secukinumab. Over the period of 2.5 years of follow-up, the NAPSI decreased by $73.3 \%$ and $63.3 \%$, depending on the dose of secukinumab - 300 and $150 \mathrm{mg}$, respectively [43]. The AMAGINE-2 and AMAGINE-3 studies show that complete remission of nail lesions occurred in $63.8 \%$ of patients using brodalumab and $39.1 \%$ of patients using ustekinumab for 52 weeks [44]. According to some authors, patients who did not respond to therapy with IL-17 inhibitors may benefit from the use of TNF antagonists [45]. However, further research is needed in this regard. It is worth adding that the effectiveness of adalimumab increased in the 52-week follow-up compared to the results obtained in week 26 , which suggests the need for long-term treatment of nail psoriasis [46].

Also noteworthy are the OPT Pivotal 1 and OPT Pivotal 2 studies, which showed that tofacitinib was effective in reducing nail disease symptoms compared to placebo. In the week 16 from the start of treatment with the dose of $5 \mathrm{mg}$ and $10 \mathrm{mg}$ twice a day, a complete recovery of nail lesions was found in $10 \%$ and $18 \%$ of patients, respectively. At week 52, results improved and amounted to $16 \%$ and $29 \%$, respectively [47]. The use of apremilast in the treatment of nail psoriasis seems to be a promising option, however, effectiveness of this drug must be confirmed in larger groups of patients $[48,49]$.

\section{CONCLUSIONS}

Clinical trials and meta-analyzes suggest that IL-17 inhibitors, primarily ixekizumab, are the best biological treatment option for nail psoriasis. This group of drugs seems to provide optimal control of psoriasis
Opublikowane ostatnio przeglądy systematyczne i metaanalizy potwierdzają, że wszystkie stosowane w łuszczycy leki biologiczne i drobnocząsteczkowe skutkują poprawą kliniczną w zakresie zmian paznokci w 10.-16. tygodniu i 24.-26. tygodniu leczenia w porównaniu z placebo. Najlepsze wyniki zaobserwowano podczas podawania iksekizumabu, etanerceptu i tofacytynibu [35-37]. Całkowite ustąpienie objawów jest najbardziej prawdopodobne po leczeniu iksekizumabem, a w dalszej kolejności brodalumabem, adalimumabem, guzelkumabem, ustekinumabem i infliksymabem [38]. Na uwage zasługują wyniki badania UNCOVER-3: u pacjentów stosujących iksekizumab znaczący efekt był widoczny w 12. tygodniu terapii i w ponad 50\% przypadków osiągnięto remisję łuszczycy paznokci w 60. tygodniu leczenia [39]. Wyższą skuteczność iksekizumabu w redukcji zmian paznokciowych w porównaniu z ustekinumabem i guzelkumabem potwierdzają badania IXORA-R i IXORA-S [40, 41]. Warto dodać, że w zakresie zmian skórnych odpowiedź na leczenie iksekizumabem u chorych bez zajęcia oraz z zajęciem paznokci była podobna [42]. W badaniu TRANSFIGURE stwierdzono długotrwale utrzymującą się poprawę łuszczycy paznokci i jakości życia pacjentów podczas stosowania sekukinumabu. W 2,5-rocznej obserwacji uzyskano zmniejszenie NAPSI o 73,3\% i 63,3\% w zależności od dawki sekukinumabu - odpowiednio 300 i 150 mg [43]. Z badań AMAGINE-2 i AMAGINE-3 wynika, że w czasie 52-tygodniowego leczenia całkowita remisja zmian paznokciowych wystąpiła u 63,8\% chorych stosujących brodalumab i 39,1\% pacjentów stosujących ustekinumab [44]. Zdaniem niektórych autorów pacjenci, którzy nie zareagowali na terapię inhibitorami IL-17, mogą odnieść korzyść po zastosowaniu antagonistów TNF [45]. Konieczne są jednak dalsze badania pod tym kątem. Warto dodać, że skuteczność adalimumabu zwiększyła się w 52. tygodniu obserwacji w stosunku do wyników uzyskanych w 26. tygodniu, co sugeruje konieczność prowadzenia długoterminowego leczenia łuszczycy paznokci [46].

Na uwagę zasługują także badania OPT Pivotal 1 i OPT Pivotal 2 wskazujące na skuteczność tofacytynibu w redukcji objawów chorobowych dotyczących płytek paznokciowych $\mathrm{w}$ porównaniu z placebo. W 16. tygodniu od rozpoczęcia leczenia dawką $5 \mathrm{mg}$ i $10 \mathrm{mg} 2$ razy dziennie stwierdzono całkowite ustąpienie zmian paznokci u odpowiednio 10\% i 18\% chorych. W 52. tygodniu wyniki polepszyły się i wynosiły odpowiednio $16 \%$ i 29\%, [47]. Zastosowanie apremilastu w terapii łuszczycy paznokci wydaje się obiecującą opcją, jednak skuteczność tego leku musi zostać potwierdzona w większych grupach pacjentów [48, 49].

\section{PODSUMOWANIE}

Badania kliniczne i metaanalizy sugerują, że najlepszą opcją leczenia biologicznego łuszczycy paznokci są inhibitory IL-17, przede wszystkim iksekizumab. Grupa 
also in other difficult-to-treat areas, where IL-23 inhibitors are also important. However, comparing data provided in the literature is difficult given the variety of methods used for clinical evaluation. Further headto-head and real-world testing is required.

\section{CONFLICT OF INTEREST}

The authors declare no conflict of interest.

\section{References}

Piśmiennictwo

1. Larsabal M., Ly S., Sbidian E., Moyal-Barracco M., Dauendorffer JN., Dupin N., et al.: A French prospective study assessing instantaneous prevalence, clinical features and impact on quality of life of genital psoriasis among patients consulting for psoriasis. Br J Dermatol 2019, 180, 647-656.

2. Augustin M., Sommer R., Kirsten N., Danckworth A., Radtke MA., Reich K., et al.: Topology of psoriasis in routine care: results from high-resolution analysis of 2009 patients. Br J Dermatol 2019, 181, 358-365.

3. Egeberg A., See K., Garrelts A., Burge R.: Epidemiology of psoriasis in hard-to-treat body locations: data from the Danish skin cohort. BMC Dermatol 2020, 20,3.

4. Merola JF., Li T., Li W.Q., Cho E., Qureshi A.A.: Prevalence of psoriasis phenotypes among men and women in the USA. Clin Exp Dermatol 2016, 41, 486-489.

5. Hawro M., Maurer M., Weller K., Maleszka R., Zalewska-Janowska A., Kaszuba A., et al.: Lesions on the back of hands and female gender predispose to stigmatization in patients with psoriasis. J Am Acad Dermatol 2017, 76, 648-654.e2.

6. Alpsoy E., Polat M., FettahlıoGlu-Karaman B., Karadag A.S., Kartal-Durmazlar P., YalCin B., et al.: Internalized stigma in psoriasis: a multicenter study. J Dermatol 2017, 44, 885-891.

7. Lanna C., Galluzzi C., Zangrilli A., Bavetta M., Bianchi L., Campione E.: Psoriasis in difficult to treat areas: treatment role in improving health-related quality of life and perception of the disease stigma. J Dermatolog Treat 2020, 28, 1-4.

8. da Silva N., Augustin M., Langenbruch A., Mrowietz U., Reich K., Thaçi D., et al.: Difficult-to-communicate topics and their impact on patient-centred care. PLoS One 2020, 15, e0235091.

9. Callis Duffin K., Mason M.A., Gordon K., Harrison R.W., Crabtree M.M., Guana A.I., et al.: Characterization of patients with psoriasis in challenging-to-treat body areas in the corrona psoriasis registry. Dermatology 2021, 237, 46-55.

10. Yan D., Ahn R., Leslie S., Liao W.: Clinical and genetic risk factors associated with psoriatic arthritis among patients with psoriasis. Dermatol Ther 2018, 8, 593-604.

11. Villani A.P., Boutroy S., Coutisson C., Carlier M.C., Barets L., Marotte H., et al.: Distal phalangeal bone erosions observed by HR-pQCT in patients with psoriatic onycholysis. Rheumatology 2021, 60, 1176-1184.

12. Reich A., Adamski Z., Chodorowska G., Kaszuba A., Krasowska D., Lesiak A., et al.: Łuszczyca. Rekomendacje diagnostyczno-terapeutyczne Polskiego Towarzystwa Dermatologicznego. Część 1. Dermatol Rev 2020, 107, 92-108.

13. Reich A., Adamski Z., Chodorowska G., Kaszuba A., Krasowska D., Lesiak A., et al.: Łuszczyca. Rekomendacje diagnostyczno-terapeutyczne Polskiego Towarzystwa Dermatologicznego. Część 2. Dermatol Rev 2020, 107, 110-137.

14. Sarma N.: Evidence and suggested therapeutic approach in psoriasis of difficult-to-treat areas: palmoplantar psoriasis, nail psoriasis, scalp psoriasis, and intertriginous psoriasis. Indian J Dermatol 2017, 62, 113-122.

15. Camela E., Ocampo-Garza S.S., Cinelli E., Villani A., Fabbrocini G., Megna M.: Therapeutic update of biologics and small molecules for scalp psoriasis: a systematic review. Dermatol Ther 2021, 34, e14857.

16. Alsenaid A., Ezmerli M., Srour J., Heppt M., Illigens B.M., Prinz J.C.: Biologics and small molecules in patients with scalp psoriasis: a systematic review. J Dermatolog Treat 2020, 1-10. doi: 10.1080/09546634.2020.1770167.

17. Menter A., Warren R.B., Langley R.G., Merola J.F., Kerr L.N., Dennehy E.B., et al.: Efficacy of ixekizumab compared to etanercept and placebo in patients with moderate-to-severe plaque psoriasis and non-pustular palmoplantar involvement: results from three phase 3 trials (UNCOVER-1, UNCOVER-2 and UNCOVER-3). J Eur Acad Dermatol Venereol 2017, 31, 1686-1692.

18. Ryan C., Menter A., Guenther L., Blauvelt A., Bissonnette R., Meeuwis K., et al.: Efficacy and safety of ixekizumab in a randomized, double-blinded, placebo-controlled phase IIIb study of patients with moderate-to-severe genital psoriasis. Br J Dermatol 2018, 179 , 844-852.

19. Foley P., Gordon K., Griffiths C.E.M., Wasfi Y., Randazzo B., Song M., et al.: Efficacy of guselkumab compared with adalimumab and placebo for psoriasis in specific body regions: a secondary analysis of 2 randomized clinical trials. JAMA Dermatol $2018,154,676-683$.

20. Megna M., Cirillo T., Balato A., Balato N., Gallo L.: Real-life effectiveness of biological drugs on psoriatic difficult-to-treat body regions: scalp, palmoplantar area and lower limbs. J Eur Acad Dermatol Venereol 2019, 33, e22-e23.

21. Megna M., Fabbrocini G., Ruggiero A., Cinelli E.: Efficacy and safety of risankizumab in psoriasis patients who failed anti-IL-17, anti12/23 and/or anti IL-23: preliminary data of a real-life 16-week retrospective study. Dermatol Ther 2020, 33, e14144.

22. Megna M., Cinelli E., Gallo L., Camela E., Ruggiero A., Fabbrocini G.: Risankizumab in real life: preliminary results of efficacy and safety in psoriasis during a 16-week period. Arch Dermatol Res 2021, doi: 10.1007/s00403-021-02200-7.

23. Lanna C., Zangrilli A., Bavetta M., Campione E., Bianchi L.: Efficacy and safety of adalimumab in difficult-to-treat psoriasis. Dermatol Ther 2020, 33, e13374.

24. Guarene M., Pasi A., Bolcato V., Cananzi R., Piccolo A., Sbarsi I., et al.: Presence of HLA-A Bw4-80I KIR ligands could predict “ difficult-to-treat" psoriasis and poor response to etanercept. Mol Diagn Ther 2018, 22, 471-474. 
25. Carrascosa J.M., Del-Alcazar E.: Apremilast for psoriasis treatment. G Ital Dermatol Venereol 2020, 155, $421-433$.

26. Van Voorhees A.S., Stein Gold L., Lebwohl M., Strober B., Sofen H., Papp K., et al.: Efficacy and safety of apremilast in patients with moderate to severe plaque psoriasis of the scalp: results up to 32 weeks from a randomised, phase 3 study. Br J Dermatol 2021, doi: 10.1111/bjd.20083.

27. Rigopoulos D., Baran R., Chiheb S., Daniel $3^{\text {rd }}$ C.R., Di Chiacchio N., Gregoriou S., et al.: Recommendations for the definition, evaluation, and treatment of nail psoriasis in adult patients with no or mild skin disease: a dermatologist and nail expert group consensus. J Am Acad Dermatol 2019, 81, 228-240.

28. Choudhary P., Mehta R.D., Ghiya B.C., Sharma D.: Treatment of nail psoriasis with intramatrical methotrexate: an uncontrolled prospective study of 20 patients. J Am Acad Dermatol 2021, 84, 526-528.

29. Özkur E., Kıvanç Altunay İ., Oğuz Topal İ., Aytekin S., Topaloğlu Demir F., Özkök Akbulut T., et al.: Switching biologics in the treatment of psoriasis: a multicenter experience. Dermatology 2021, 237, 22-30.

30. Tokuyama M., Ota M., Saitoh R., Sawamura M., Okitsu N., Shimizu T., et al.: Biological retention rates, the reasons of switching, and prognostic factors in patients with psoriasis treated biologics. Tokai J Exp Clin Med 2020, 45, 230-235.

31. Bardazzi F., Lambertini M., Chessa M.A., Magnano M., Patrizi A., Piraccini B.M.: Nail involvement as a negative prognostic factor in biological therapy for psoriasis: a retrospective study. J Eur Acad Dermatol Venereol 2017, 31, 843-846.

32. Demirsoy E.O., Kuran R., Salman S., Cağlayan C., Aktürk A.S., Bayramgurler D., et al.: Effectiveness of systemic treatment agents on psoriatic nails: a comparative study. J Drugs Dermatol 2013, 12, 1039-1043.

33. Tosti A., Ricotti C., Romanelli P., Cameli N., Piraccini B.M.: Evaluation of efficacy of acitretin therapy for nail psoriasis. Arch Dermatol $2009,145,269-271$.

34. Gumusel M., Ozdemir M., Mevlitglu I., Bodur S.: Evaluation of the efficacy of methotrexate and cyclosporine therapies on psoriatic nails: a one-blind, randomized study. J Eur Acad Dermatol Venereol 2011, 25, 1080-1084.

35. Huang I.H., Wu P.C., Yang T.H., Li H., Huang Y.T., Cheng Y.C., et al.: Small molecule inhibitors and biologics in treating nail psoriasis: a systematic review and network meta-analysis. J Am Acad Dermatol 2021, S0190-9622(21)00168-7.

36. Szebényi J., Gede N., Hegyi P., Szakács Z., Solymár M., Eróss B., et al.: Efficacy of biologics targeting tumour necrosis factor-alpha, interleukin-17 -12/23,-23 and small molecules targeting JAK and PDE4 in the treatment of nail psoriasis: a network meta-analysis. Acta Derm Venereol 2020, 100, adv00318.

37. Zhang X., Xie B., He Y.: Efficacy of systemic treatments of nail psoriasis: a systemic literature review and meta-analysis. Front Med $2021,8,620562$

38. Reich K., Conrad C., Kristensen L.E., Smith S.D., Puig L., Rich P., et al.: Network meta-analysis comparing the efficacy of biologic treatments for achieving complete resolution of nail psoriasis. J Dermatolog Treat 2021, 1-9. doi: 10.1080/09546634.2021.1892024.

39. van de Kerkhof P., Guenther L., Gottlieb A.B., Sebastian M., Wu J.J., Foley P., et al.: Ixekizumab treatment improves fingernail psoriasis in patients with moderate-to-severe psoriasis: results from the randomized, controlled and open-label phases of UNCOVER-3. J Eur Acad Dermatol Venereol 2017, 31, 477-482.

40. Wasel N., Thaçi D., French L.E., Conrad C., Dutronc Y., Gallo G., et al.: Ixekizumab and ustekinumab efficacy in nail psoriasis in patients with moderate-to-severe psoriasis: 52-week results from a phase 3, head-to-head study (IXORA-S). Dermatol Ther 2020, 10, 663-670.

41. Blauvelt A., Leonardi C., Elewski B., Crowley J.J., Guenther L.C., Gooderham M., et al.: A head-to-head comparison of ixekizumab vs. guselkumab in patients with moderate-to-severe plaque psoriasis: 24-week efficacy and safety results from a randomized, doubleblinded trial. Br J Dermatol 2021, 184, 1047-1058.

42. Rich P., Goldblum O., Disch D., Lin C.Y., Merola J.F., Elewski B.: Nail psoriasis does not affect skin response to ixekizumab in patients with moderate-to-severe psoriasis. J Drugs Dermatol 2020, 19, 741-746.

43. Reich K., Sullivan J., Arenberger P., Jazayeri S., Mrowietz U., Augustin M., et al.: Secukinumab shows high and sustained efficacy in nail psoriasis: 2.5-year results from the randomized placebo-controlled TRANSFIGURE study. Br J Dermatol 2021, 184, 425-436.

44. Elewski B., Rich P., Lain E., Soung J., Lewitt G.M., Jacobson A.: Efficacy of brodalumab in the treatment of scalp and nail psoriasis: results from three phase 3 trials. J Dermatol Treat 2020, doi: 10.1080/09546634.2020.1749546.

45. Komatsu-Fujii T., Honda T., Otsuka A., Kabashima K.: Inverse responses of the skin and nail lesions of psoriatic arthritis to an antiinterleukin-17A antibody and an anti-tumor necrosis factor-alpha antibody. J Dermatol 2019, 46, e440-e441.

46. Elewski B.E., Baker C.S., Crowley J.J., Poulin Y., Okun M.M., Calimlim B., et al.: Adalimumab for nail psoriasis: efficacy and safety over 52 weeks from a phase-3, randomized, placebo-controlled trial. J Eur Acad Dermatol Venereol 2019, 33, 2168-2178.

47. Merola J.F., Elewski B., Tatulych S., Lan S., Tallman A., Kaur M.: Efficacy of tofacitinib for the treatment of nail psoriasis: two 52 -week, randomized, controlled phase 3 studies in patients with moderate-to-severe plaque psoriasis. J Am Acad Dermatol 2017, 77, 79-87.e1.

48. Lanna C., Cesaroni G.M., Mazzilli S., Vollono L., Gaziano R., Marino D.: Apremilast as a target therapy for nail psoriasis: a real-life observational study proving its efficacy in restoring the nail unit. J Dermatolog Treat 2020, doi: 10.1080/09546634.2020.1801976.

49. Magdaleno-Tapial J., Valenzuela-Oñate C., Ortiz-Salvador J.M., Subiabre-Ferrer D., Hernández-Bel P.: Effective treatment of nail psoriasis with apremilast: report of two cases and review of the literature. Dermatol Online J 2018, 24, 13030/qt27x34947.

Received: 20.05 .2021

Accepted: 5.06.2021

Otrzymano: 20.05.2021 r

Zaakceptowano: 5.06.2021 r. 